\title{
Islamic Cosmology of Accounting: an Introduction
}

Amelia Indah Kusdewanti

Peneleh Research Institute, Jl. Warung Buncit Raya No. 405, Jakarta Ameliaindah15@gmail.com

ARTICLE INFO

Article history

Received 27 January 2019

Revised 8 February 2019

Accepted 1 April 2019

Keywords

Cosmology

Philosopical Foundation

Islamic accounting

\begin{abstract}
This article aims to explore new accounting philosophical foundation in the sight of cosmological term. Using literature study this article shows the need of creating that new philosophical term and radically explain the impact toward creation of civilization. The result shows how inadequate accounting philosophical foundation then cause fragmented accounting reality. It also shows us trapped in materialism world and apart from all other aspect, ie sociology, anthropology, as well as religion. Islamic Cosmology of accounting is philosophy of the wholeness built based on Tauhid.
\end{abstract}

This is an open access article under the CC-BY-SA license.

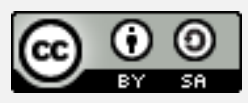

\section{Introduction}

This article aims to build a new philosophical foundation for accounting as a science so that it can contribute to the achievement of prophetic civilization. Contrary to the focus of mainstream accounting which focuses solely on the methodology alone (Christenson, 1983), and ignores its role in society (Chua, 1986), and nature (Chewakak \& Young, 2003) even accounting is considered to have rationalized a silence not only in nature (Chwastiak \& Young, 2003), but have contributed to the destruction of the human race (Chwastiak, 1999, 2006) arguing for e-efficiency, also having "deceived" the community (Chwastiak, 1999). The new philosophy taken from the thought of Islamic cosmology has consequences for the cosmos, and has consequences for the way of thinking and forming ways of living justly towards prophetic civilization.

Due to the crisis experienced by accounting, several studies emerged in the field of ethics and values, even for decades the study of accounting and religion has evolved because religion is a source of value, to the emergence of Islamic accounting / accounting. Just name the study from (Gallhofer \& Haslam, 2004; Kamla, Gallhofer, \& Haslam, 2006) how religion becomes a liberation theology in accounting that is trapped in materialism. Also studies of accounting and religion (McPhail, Gorringe, \& Gray, 2004) although there are still distinctions between sacred and profane. Even so in Reijius society, their religious beliefs will influence how their ways of life, including carrying out accounting, including how the cosmological outlook in the Kingdom of Siam, Thailand influences the king's policies and the way of life of the people (Kuasirikun \& Constable, 2010).

Both from socialists, critical radicals and radical humanists, as well as postmodern, all of them want to provide an improvement in the accounting conditions that crisis these values. But socialist accounting as well as critical radicals and humanists, for example (Mulawarman \& Kamayanti, 2018a) only provide for the defense of material distribution justice, but do not provide a clear direction for the formation of a whole society. Religion for them like the marx is considered as opium. Postmodern will eventually lead to chaos vortices because it rejects essential order and permanence. Both do not provide space for God. The socio-cultural interactions that occur are only thought to be based on values that are reproduced continuously by the mind. Of course the methodological impact although different remains far from the vortex of transcendence values. 
The reality of accounting that is realized to be born from things that are "profane" triggers the birth of accounting that has a sacred nature (Jacobs, 2005). This shows that the thought of the importance of accounting built from the sacred context itself is crucial in determining how accounting will grow in the future, especially those that eventually lead to Islamic / sharia accounting (Baydoun \& Willet, 2000; Baydoun \& Willett, 1993; Editors, Aston, \& Kamla, 2011). The birth of Islamic accounting was triggered by the affirmation of the rejection that accounting was born from a materialistic capitalist womb which could also lead to the formation of a materialistic society. (Kuasirikun \& Constable, 2010) shows how cosmological thinking actually existed in the 19th century in Thailand, and of course it had an effect on the formation of society in its time. The problem now is that the development of Islamic accounting still cannot be completely separated from conventional thinking, this is raised (Kamla, 2009).

Even so there are some accounting thoughts that put forward or debate about the existence of religion in (development) accounting, still consider religion as a product of social and cultural interactions see (Jacobs, 2005; Kuasirikun \& Constable, 2010; McKernan \& Kosmala, 2007). This article contributes to the reappointment of the reality of accounting that really originates from a cosmological religion, which is a tradition of Islamic thinking since the 13th century. Thus the reality that results from this thinking is a cosmological reality which ultimately forms interactions socially, culturally, and politics. This means that the reality presented does not stand alone, both sociology, and anthropology are the results of a cosmological perspective that is metaphysicallyreligious.I believe that this happens not because of a mere technical error, but fundamentally is a mistake in the order of values that exist in Accounting which causes a crisis of value. This error is also not methodological, but the error of perspective and "belief" even the fault of his philosophy.

Therefore I want to build a tradition of philosophy and a new tradition of thinking for accounting which also has consequences for its values and methodology, namely the way of thinking cosmology. The cosmology that will be described here is a metaphysical cosmology from Syakhul Akbar Ibn 'Arabi. This is to form a new understanding that every socio-cultural interaction that occurs and the interaction of both of them with religious values is not a product of mere thought. The interaction of religion with all fields (social, economic, cultural, political) both jointly and separately produces a primary value, which with the creative power of dynamic reasoning, then develops according to the way of life and influences the way of life.

I will depart from Islamic civilization, how in contrast has a different development from western civilization in the past. This approach is called the diachronic approach (Mulawarman \& Kamayanti, 2018b). Islamic civilization does not start from materialism, but belief in the Haqq, and with this basic foundation then develops into a creative way of thinking about the creation of the universe (cosmology) and all the knowledge that covers it (Nasr, 2001) which ultimately forms the golden civilization order. I want to bring this cosmological way of thinking into the realm of accounting. The structure of this article consists of an introduction, modern / existing accounting conditions and criticism of its philosophy, concept of unity, interconnection reality and beyond, cosmology and consequences in history, and conclusion

\section{Method}

This article uses philosophical thinking by questioning the foundational foundations of the accounting philosophy, using various metaphors to describe current accounting realities as criticisms (Amernic, 1996; Arrington \& Schweiker, 1992). It does not stop there, this research also takes a diachronic approach to look for past life forms, especially prophetic traditions in building civilization (Mulawarman \& Kamayanti, 2018a). The cosmological way of thinking is the basic foundation of the formation of Islamic civilization in the past, many great scientists such as Ibn Sina, Al Khawarij, Al Arabi used cosmological thinking in scientific development in various fields such as medicine, mathematics and Sufism (Nasr, 1978, 2001). After doing diachronic over past values, then synchronized to form the scientific construction of the philosophical foundation of accounting. 


\section{Results and Discussion}

\subsection{The condition of modern accounting and criticism of its philosophy}

"In search of accounting philosophy" (Engelmann, 1954) triggers us to rethink the need to find philosophical roots from accounting. At that time there was an issue that philosophy was actually not important in accounting, so it did not need to be discussed and even Friedman (Friedman, 1970) himself emphasized that the most important thing was the methodology so that accounting studies were fixed only on its methodology. Until finally the awareness of the importance of philosophy in accounting, and the relationship was pushed to the surface.(Tinker, Merino, \& Neimark, 1982) reveal a very interesting statement, that modern accounting philosophy rooted in empiricism and rationalism (logical positivist) is only a "mask" to cover the ideology of conservatism.

According to him and also (Chabrak, 2012), accounting with laden value is only camouflage to cover the hidden agenda to create a well-established order of accounting (capitalism), so that what Gray might reveal is to create an accountable world order, with the aim of controlling the world.This is very interesting because in the realm of science (accounting), the ways in which science is considered scientific based on the tradition of empiricism and rationalism accounting are to get consensus with the scientific society of accounting (Tinker et al., 1982). Of course the recognition of "scholarship" in accounting is not entirely objective, as has been predicted, but on the contrary it is very subjective.

\subsection{Diachronich Analysis of Unity}

'Laa ilahailallah Muhammaddar Rasulullah", this sentence is a sentence of tauhid. Tawhid is an acknowledgment of the oneness of Allah, also the recognition that the Messenger of Allah is a messenger of Allah. Tawhid becomes the root of the whole foundation of Muslim life, Tawheed is not only implemented in obligatory worship and ritual sunnah, but in substance, Tawheed is also upheld in daily life, as part of a network of universal organisms, both at a small level like family, and at the macro level, namely the wider community and civilization (Faruqi 1997). The implications of Tawhid include social, economic, cultural, and even political life. All of them are based on unity.

In the development of science the laying of the foundations of unity in the history of Muslims has been carried out since the 7th century AD. Development of science such as mathematics, physics, biology, astronomy, until philosophy is based on Tawhid. Leading scientists such as Ibn Sina, in his education before he wrote the masterpiece of Ibn Syifa, at the age of 7 years, he was educated to memorize the Qur'an. After that he was entrusted by his father to a prominent mathematics teacher in his day (Nasr 2001). His father laid the foundations of the monotheism first by educating him to study the Qur'an and Hadith before learning other sciences. This means that in the history of the development of Muslim scientists in creating knowledge, Tawheed has been embedded as faith while forming a way of looking at the formation of science.

In this discussion I will talk about Islamic cosmology. Islamic cosmology is very different from general cosmology. Islamic cosmology is not only about how the universe happened, but also related to metaphysics in Islam itself regarding the creation of a world that starts from a process involving metaphysics, namely the essence of Allah. In the view of Islamic cosmology, cosmos or universe is a manifestation of God's emanation, in the universe there are divine names and archetypes. True reality in this world is one, because it comes from the Haqq (Al Attas, 2001). The reality of this haqq is a reflection of the confession of the sentence of Tawheed, namely creed.

Recognition of Tawheed has consequences for our recognition that the reality in this world is one. This recognition is not historical, and is derived from intellectual or innate knowledge of human nature. Unity of reality also has consequences for the views of being (the theory of existence), everything in this world is non-existent, only Allah is the one who exists. These ontological characteristics have logical consequences for the ways in which knowledge of monotheism is taken. As mentioned above, in the Islamic tradition there are two types of knowledge, namely knowledge that is innate and knowledge that is transmittable, which is taught by the previous teachers.

Both types of knowledge are rooted in unity, and to find divine archetypes in cosmos. Indeed a science or knowledge is not created by humans, but is only found, because all of them come from 
the single reality of the Supreme Being. Then with this knowledge and the attributes of knowledge / faculties of knowledge that exist within man, it is used to reveal the divinity of divinity.

The first type of knowledge that is innate / fitrah has been embedded in human transcendental consciousness. This is as described in the letter Al A'raf 102 which is an acknowledgment of the oneness of Allah SWT. Minutes brought by the Prophets and the Apostles are a reminder of the testimony of our spirits on the oneness of Allah who at that time was in the realm of barzakh. The second type of knowledge that is transmitted is shaped like the science of Kalam, as well as sharia which is taught through previous teachers from generation to generation. This knowledge is obtained from various interpretive methods for the verses of the Qur'an and the AL Hadith. Indirectly the type of knowledge above illustrates the epistemological character of science from Islam. Science does not only come from empirical and sensory material, but even transcendental experience is a science.

This character of the unity of reality later became the cosmological basis for the formation of sciences. One of the scientists who brought down the mathematics of this cosmological concept was AL Kwarijmi. He not only created mathematics as a very technical calculating concept, but also provided a philosophical spirit, for example with the number 0 which means empty but also an absolute, while 1 means there is, exists. The process of creating a universe on this earth starts from number 0 to 1, and will return to 0 again, an absolute which is Alpha and Omega. This reality arises and is present because of a cosmological perspective. So all that is in this realm is called realityreal-haqq-haqiqah if it contains the number 0 which emanates into the aspect of life, if it negates the number 0 as all sources of life, then it cannot be called a reality. Accounting, which negates the number 0 as its genomes, does not contain a reality (truth-haqq-haqiqah).

\subsection{Interconnection Reality and Beyond}

In the cosmological view, humans and the cosmos (other creations of God) are connected because they are all emanations of divine reality. Chittik divided it into two mentions, he took this interpretation from the rules or intellectual traditions of Islam. There is a large cosmos and a small cosmos, even in the Javanese tradition this is referred to as the universe and the universe. The great cosmos is nature, while the small cosmos is human. Chittick calls it a subject and an Object, but I think that the mention of this will give rise to the distance between the small cosmos and the large cosmos, even though both are single realities, even so interactions that arise in social life actually have a very deep connection between one aspect and aspects another. Mahzar intelligently divides this level of reality into a matrix to show a connection between reality. Politics, social, economics, and culture are studies that focus on humans as the main subjects in their studies, so they are anthropocentric. However, if with this cosmological paradigm, then humans are not the center of the universe, the center of this universe is singular, namely Allah. Humans have their own function and purpose because they occupy the important coordinate lines to reach rahmatan lil 'alamin.

Chittik (2003) mentions this connection as a vision of an anthropocosmic vision, this vision describes how the connection between humans and nature, the small cosmos and the great cosmos, where in fact they are like a mirror, and have character and similarity. Therefore, to see a deep connection that departs from the unity of reality, the three main things that are very important to be studied in terms of cosmology are metaphysical, intellectual, and psychology of human soul reality.

Psychology of human soul is an important issue to look back on human goals and their creation in order to bring the vision of rahmatan lil alamin. Humans come from the word Nas-Nasiyah which means Forgetting (Al Attas, 2001). As Chittick revealed, prophetic missions carrying treatises are a form of reminder to return to human nature. It aims to look back on the human potential by using intellectuals. This is different from modern science that intellectuals are only reduced to reason. Reason is only a form of reasoning which is considered logical, while intellectuals in the Islamic tradition encompass broader and deeper rules. Therefore to see the connectedness of intellectual reality used by humans beyond the use of the five senses. Epistemologically, the heart is also used by humans to gain knowledge that is not obtained in logical reasoning processes.

Actually if we explore more in the process of reasoning logically itself is present because of an idea about the world where there is only material. All materialized from the material, the universe can expand and disintegrate because the process of moving objects that are considered dead with a 
machine-like movement, then the material premise $\mathrm{Y}$ is caused by $\mathrm{X}$. Material causality is then a typical way of thinking modernity, and mechanistic, because it is not there is any power that is not visible, capable of moving an object in this universe. This refusal then becomes the dominant way of thinking in logical reasoning.

This dominant and logical way of thinking later became a perspective in the formation of modern science, including accounting in it. This perspective is an ontological dimension, while the senses used to obtain empirical knowledge are epistemological factors. The consequence that arises next is that the emerging reality is empirical which cannot penetrate the single reality that is transcendence. So this is not called reality because it does not reflect a single reality. This method of logical reasoning is also related to the view of modern humans in accounting, which is called Homo Economicus, a man who bases himself as a materialistic figure.

The consequence of this view is that humans in the fulfillment of their needs are always based on economic factors, profits, losses for themselves. Nature is an object or object that has the right to be controlled in such a way as to benefit the whole person. Modern accounting does not consider how culture, way of life, ideologically descending ways of thinking can shape the lives of society and civilization in the end. Meanwhile, if we look back, the way of thinking influences how human life is in economic, social, political and cultural ways.

Later the issue of technology has changed, perhaps forever the face of our civilization. Technology becomes something deified to replace God because it is considered capable of meeting the needs and at the same time fighting against the full nature of human beings, namely destiny and mortality. Even this is a form of view that is very material.

\section{Conclusion}

This article is a criticism of the development of modern accounting that has experienced problems in its philosophical foundation. Therefore it is necessary to build a new foundation that is able to bring better civilization. The current condition of modern accounting can not be separated from the values of mastery and very far from the distribution of justice promised in the rhetoric of equality and freedom carried in every rhetoric and accounting discourse. Consequently, technically, market dominance appears, reflected in market price movements, reflecting the liberalization of modern life.Cosmology brings the view of the holster that departs from Tawhid. In a diachronic approach, cosmology is the pulse of all science in the golden age of Islamic civilization in forming prophetic / civilization civilizations. With this principle, the scientific foundation that starts from natural sciences such as physics, biology, astronomy to social science culture cannot be separated from Tauhid which is the root of all scientific development. Even so, in accounting, cosmology as the basis of accounting will bring prophetic values that are pervasive in every life of integrated accounting as a form of values of worship to God.

This form of rejection of the highest reality manifests itself in people's lives today, especially the echo of devised technological discourse to advance human life, but also brings a dark side which also brings people against their own nature as beings who will return to Allah. This resistance is a project that was triggered to make humans fight death which has been feared in modern life.

The consequence of this thinking is a form of accounting as a technology that does not have interactive idealism for life other than humans, such as nature, animals, plants and others such as angels. Of course, it can be seen from the components of financial statements which are the basis of accounting output, where the accumulation of material is the main objective of accounting.

For this reason, it is necessary to develop a holistic concept that not only includes the connectedness of reality between people, nature and God, but also a constructive concept that will eventually become the basis of civilization development in the end, including social, political, cultural integration that is present in every interaction humans today, coupled with an era of technology that is so massive and informed, it is necessary to have a fence to keep track of the coveted civilization. 


\section{References}

Amernic, J. H. (1996). The rhetoric versus the reality, or is the reality "mere" rethoric? A case study of public accounting firms' responses to a company's invitation for alternative opinions on an accounting matter. Critical Perspectives on Accounting, 7(April 1995), 57-75. https://doi.org/10.1006/cpac.1996.0008

Arrington, E. C., \& Schweiker, W. (1992). THE RHETORIC AND RATIONALITY OF ACCOUNTING RESEARCH. Accounting, Organizations and Society, 17(6), 511-533.

Baydoun, N., \& Willet, R. (2000). Islamic corporate reports. Abacus, 36(1), 71-90. https://doi.org/10.1111/1467-6281.00054

Baydoun, N., \& Willett, R. (1993). Islamic Accounting Theory. In The AAANZ Annual Conference (pp. 1-19).

Chabrak, N. (2012). Money talks : the language of the Rochester School. https://doi.org/10.1108/09513571211209608

Christenson, C. (1983). The methodology of positive accounting. Accounting Review, LVIII(1), 122. https://doi.org/DOI:

Chua, W. F. (1986). Radical Development in Accounting Thought. The Accounting Review, 61(4), 601-632.

Chwastiak, M. (1999). Accounting and the Cold War: the Transformation of Waste Into Riches. Critical Perspectives on Accounting, 10(June 1998), 747-771. https://doi.org/10.1006/cpac.1998.0276

Chwastiak, M. (2006). Rationality, performance measures and representations of reality: Planning, programming and budgeting and the Vietnam war. Critical Perspectives on Accounting, 17, 29-55. https://doi.org/10.1016/j.cpa.2004.05.006

Chwastiak, M., \& Young, J. J. (2003). Silences in annual reports. Critical Perspectives on Accounting, 14(5), 533-552. https://doi.org/10.1016/S1045-2354(02)00162-4

Editors, G., Aston, O. A., \& Kamla, R. (2011). Islam, accounting and society. Accounting Forum, 35(4), 287. https://doi.org/10.1016/j.accfor.2011.10.001

Engelmann, K. (1954). in Search of an Accounting Philosophy. Accounting Review. Retrieved from http://www.lib.lsu.edu/apps/onoffcampus.php?url=http://search.ebscohost.com/login.aspx?dir ect=true \% 7B \&\%7Ddb=bth\%7B \&\%7DAN=7110300\%7B \&\%7Dsite=ehostlive $\% 7 \mathrm{~B} \& \% 7 \mathrm{Dscope}=$ site

Friedman, M. (1970). Essays in Positive Economics. University of Chicago Press, II(1953), 3-35. https://doi.org/DOI:

Gallhofer, S., \& Haslam, J. (2004). Accounting and liberation theology. Accounting, Auditing \& Accountability Journal, 17(3), 382-407. https://doi.org/10.1108/09513570410545795

Jacobs, K. (2005). The sacred and the secular: examining the role of accounting in the religious context. Accounting, Auditing \& Accountability Journal, 18(2), 189-210. https://doi.org/10.1108/09513570510588724

Kamla, R. (2009). Critical insights into contemporary Islamic accounting. Critical Perspectives on Accounting, 20(8), 921-932. https://doi.org/10.1016/j.cpa.2009.01.002

Kamla, R., Gallhofer, S., \& Haslam, J. (2006). Islam, nature and accounting: Islamic principles and the notion of accounting for the environment, 30, 245-265. https://doi.org/10.1016/j.accfor.2006.05.003

Kuasirikun, N., \& Constable, P. (2010). The cosmology of accounting in mid 19th-century Thailand. Accounting, Organizations and Society, 35(6), 596-627. https://doi.org/10.1016/j.aos.2010.01.004

McKernan, J. F., \& Kosmala, K. (2007). Doing the truth: religion - deconstruction - justice, and accounting. Accounting, Auditing \{\&\} Accountability Journal, 20(5), 729-764. https://doi.org/10.1108/09513570710779027

McPhail, K., Gorringe, T., \& Gray, R. (2004). Accounting and theology, an introduction. Accounting, Auditing \& Accountability Journal, 17(3), 320-326. https://doi.org/10.1108/09513570410545768

Mulawarman, A. D., \& Kamayanti, A. (2018a). Islamic accounting anthropology: A constructivist methodological alternative. International Journal of Business and Society, 19(S2), 302-311.

Mulawarman, A. D., \& Kamayanti, A. (2018b). Towards Islamic Accounting Anthropology. 
Journal of Islamic Accounting and Business Research, 9(4), 629-647.

https://doi.org/10.1108/jiabr-02-2015-0004

Nasr, S. H. (1978). An Introduction to Islamic Cosmological Doctrines. Great Britain: Thames and Hudsn Ltd.

Nasr, S. H. (2001). Science and Civilization in Islam. Chicago: ABC International Group.

Tinker, A. M., Merino, B. D., \& Neimark, M. D. (1982). The normative origins of positive

theories: Ideology and accounting thought. Accounting, Organizations and Society, 7(2), 167200. https://doi.org/10.1016/0361-3682(82)90019-8 